DOI 10.31558/2519-2949.2020.4.10

УДК 323.2:37.035.4:324.329

ORCID ID: https://orcid.org/0000-0003-2534-7652

Пехник А. В., Національний університет «Одеська юридична академія"

\title{
ПОЛІТИЧНІ ПРАВА ТА СВОБОДИ: АКТУАЛІЗАЦІЯ ПИТАННЯ ТА ОЦІНКА РІВНЯ ЗАБЕЗПЕЧЕННЯ
}

Актуальний аспект розгляду політичних прав та свобод полягає в регулюванні політичних прав та свобод на різних рівнях. Одне з головних питань будь-якої влади-ие довіра людей до ії інститутів. У державно-організованому суспільстві довіра людей до держави безпосередньо залежить від того, як держава гарантує та захищає права та свободи людей, наскільки держава допускає громадян до формування та реалізаџії власної волі, до участі в здійсненні державних функиій. Тут,слід звертати увагу на політичні вимоги громадян, які є предметом регулювання в рамках реалізаиії політичних прав та свобод. Саме на ие й направлене дана дослідницька робота.

Політичні права та свободи в нашому суспільстві не стали ще повноиінною політикоправовою реальністю. 3 одного боку, держава не завжди надійно забезпечує та гарантує ијі права, свободи, встановлює необтрунтовані перепони на шляху людей до використання їх же прав. 3 іншого боку, громадяни не вірять в ефективність свого впливу на владу за допомогою політичних прав, свобод. Тому виникає питання - як оцінити рівень дотримання в державі політичних прав та свобод громадян. У більшості випадків, коли здійснюється спроба дати оцінку дотримання політичних прав людини, то зазвичай використовують аналіз документів, які доступні широкому загалу. Однак такий підхід не позбавлений певних проблем, пов'язаних з неповнотою та невизначеністю даних, а також упередженим ставленням до проблеми. Оскільки не існує об'єктивних даних з даного питання то слід опиратися на фактологічний матеріал, на думки експертів з прав людини, які накопичують світовий запас знань вносять реальний внесок у поліпшення життя людей.

Ключові слова: політичні права, політичні свободи, права людини, держава, суспільство.

Постановка проблеми у загальному вигляді. Інститут прав та свобод є одним з головних в процесі демократизації. Він закріплює свободу народу і кожної людини від свавілля державної влади. На відміну від особистих, політичні права та свободи направлені на активне включення кожного громадянина в життя країни, в управління ії справами. Ці права та свободи створюють умови для закріплення зв'язків між людиною та суспільством, громадянином і державою. Від того, який стан політичних права і свобод, багато в чому залежать міцність держави, тип політичного режиму, реальність його демократизму, рівень свідомості та політичної культури населення. Разом з тим політичні права та свободи розвиваються не у відриві, а на тлі особистих прав і свобод, у взаємодії 3 ними i, перш за все, при опорі на повагу до людини.

Аналіз останніх досліджень і публікацій. Дана проблематика знаходиться в полі зору різних наукових напрямків. В рамках правового підходу питання прав та свобод людини грунтовно досліджені такими науковцями як А.Єзеров, А.Крусян, В.Кожан, Ю.Кириченко, М.Осядла, Ю.Миколаєнко, Б.Старуха, В.Погорілко, А.Селіванов, Ю.Тодика, Ю.Шемчученко, М.Фокіна та інші. Політологічний підхід представлений Л.Гураль, У.Ільницькою, О.Липчук, В. Людвік, Н.Кононенко, В.Федоренко тощо.

Метою статті є: визначити рівень актуальності щодо реалізації політичних права і свобод та окреслити критерії оцінки ступеню забезпечення державною даних прав та свобод.

Виклад основного матеріалу. Права та свободи людини, зафіксовані в міжнародних правових документах є результатом тривалого історичного формування відповідних стандартів, які стали нормою для сучасного демократичного суспільства. Окремі права та свободи людини можна виявити вже в давніх пам'ятках права. На державному рівні одним з перших реформаторів став Солон. Він провів політичну реформа, результатом якої стало розширення політичних прав громадян. Реформа Солона стала кроком вперед на шляху демократизації давньогрецького суспільства, гарантувавши 
певний набір прав для кожного класу своїм громадянам. Такі приклади, безумовно, є лише зародженням відповідних ідей щодо політичних прав та свобод.

Важливим документом на шляху становлення політичних прав став Білль про права 1791 року, який вперше на американському континенті встановив право на свободу слова, друку та право народу мирно збиратися та звертатися до уряду з петиціями про задоволення скарг. Що стосується основних принципів західноєвропейської демократії то тут слід вказати Декларації прав людини і громадянина 1789 і 1793 року, які були прийняті у Франції. Загалом, ліберальна доктрина, яка сформувалася в період буржуазних революцій, визначила основні принципи розвитку європейської цивілізації свободу, юридична рівність, верховенство закону, невідчужувані права людини, що належать їй від народження, які держава зобов'язана визнавати та захищати. Саме лібералізм визначив межі державної влади. Права людини, в ліберальній доктрині, є системою принципів та благ (як матеріальних, так і духовних), без яких нормальна життєдіяльність, розвиток індивідуальних властивостей, вільний вибір і самовизначення людини, їі реалізація як особистості, в демократичних правових державах є неможливими. Головним у ліберальній концепції є особистість та, громадянин, з їх правами та свободами, які знаходяться у центрі суспільного розвитку.

Іншого підходу дотримувалася марксистська доктрина, яка оголосила своєю головною метою встановлення нового устрою - комунізму, заснованого на принципах «справжньої» демократії, справедливості, звільнення людей від гноблення та поневолення, і в основі якої було покладено теорію класової боротьби.

Про зародження елементів інституту захисту прав людини в його сучасній інтерпретації можна говорити лише з появою перших нормативних правових актів, що регулюють такі правовідносини. саме ж формування інституту захисту зазначених прав пов'язано з виникненням Ліги Націй, а згодом з Організацією Об'єднаних Націй.

Статут ООН вперше на міжнародному рівні закріпив принцип поваги прав людини та зобов'язав держави дотримуватися основних прав і свобод. Але слід зазначити, що перелік цих прав не був визначений. Подальша робота була реалізована в Загальній декларації прав людини, у Міжнародному пакті про громадянські та політичні права, у Міжнародному пакті про економічні, соціальні і культурні права, а також у Факультативному Протоколі до Пакту про громадянські і політичні права, і в Другому факультативному протоколі.

Процес формування і вдосконалення міжнародно-правових стандартів тривав й надалі. 3 часом приймаються Конвенції, що передбачають створення систем контролю над дотриманням встановлених прав людини. Кожна 3 них стосувалася конкретного типу прав i визначала профілактичні заходи та конкретні санкції.

На думку Л.Гураль: «Політичні права та свободи - це можливості людини брати участь у державному та громадському житті, впливати на діяльність різноманітних державних органів, органів місцевого самоврядування, політичних партій та інших об'єднань громадян політичного спрямування. Вони є невід'ємними і невідчужуваними у визначених законом межах і належать кожній особі через ії людську природу» [2, с. 125].

На думку В.Бук політичні права та свободи слід розуміти як «..можливості громадян, що належать їм від народження і забезпечені законом. Ці можливості дозволяють громадянам у встановлених законом межах і формах активно впливати на організацію й діяльність держави та їі органів, органів місцевого самоврядування, інших суб’єктів політичної системи, брати участь у політичному житті» [1, с. 21]. В іншому трактуванні, політичні права та свободи визначаються як «можливості (свободи) громадянина активно брати участь в управлінні державою та громадянському житті, впливати на діяльність різних державних органів, а також громадських організацій політичної спрямованості» [10, с. 194].

Права та свободи гарантують нам право жити та займатися релігійною, політичною, інтелектуальною чи будь-якою іншою діяльністю без примусу, насильства та дискримінації. Безпосередня реалізація політичних прав та свобод починається з їх визнання державою та відповідної нормативно-правової регламентації. Україна, базуючись на міжнародно-правових актах, закріплює основні політичні права і свободи на конституційному рівні, що надає їм вищу юридичну силу. Як визначає У.Ільницька: «Політичні права і свободи, їх обсяг, повнота, гарантованість реалізації $є$ показниками рівня демократичності режиму й політичної системи, статусу особи в державі. Конституційно-правова та інституційно-організаційна гарантованість реалізації політичних прав і свобод людини і громадянина $є$ важливою формою здійснення громадського контролю за владою, механізмом самореалізації особи у політичній сфері та забезпечення ії права на участь в управлінні державними і суспільними справами» [3, с. 40-41]. 
Як правильно визначає Н.Кононенко «на відміну від прав людини, права громадянина охоплюють сферу відносин індивіда з державою (сферу публічних інтересів), надають йому інструменти впливу на зовнішню і внутрішню політику держави». Авторка акцентує увагу на тому, що «народ..... здійснює владу безпосередньо і через органи державної (законодавчої, виконавчої і судової) влади та органи місцевого самоврядування» [4, с.147].

Яким чином можна зрозуміти - на якому рівні знаходиться забезпечення цих прав в тій або іншій країні? Відповідь на це питання дасть можливість подальшого аналізу демократизації та соціально-політичного розвитку в світі. Факти порушення цих прав часто приховуються та не визнаються, інколи порушники цих прав намагаються покласти провину за свої дії на інших осіб. Спроби дати оцінку дотримання політичних прав людини здебільшого спираються на документи, які доступні широкому загалу. Однак такий підхід не позбавлений певних проблем, пов'язаних 3 неповнотою та невизначеністю даних, а також упередженим ставленням до проблеми. Оскільки не існує об'єктивних даних з даного питання то слід опиратися на фактологічний матеріал, на думки експертів з прав людини, які накопичують світовий запас знань вносять реальний внесок у поліпшення життя людей.

Можна визначити критерії щодо політичних прав людини, кожен з яких базувався на положеннях міжнародного права: право на свободу зборів та асоціацій, право на політичну думку та переконання, право приймати участь в управлінні країною. В. Федоренко визначає, що «....політичні права та свободи, передбачені Конституцією та законами України, є правовим підгрунтям політичної участі громадян в управлінні державними справами» $[11$, с.86].

Щодо ознак, слід звернутися до думки В.Людвіка, який вважає, що їх слід охарактеризувати «на прикладі такої властивості, як пряма дія. Пряма дія політичних прав і свобод означає відсутність необхідності отримувати дозволу на їх реалізацію та використання; можливість захищати ці права в судовому порядку та іншими законними способами; здійснення безпосередньо на підставі норм Основного Закону» $[6$, с.380].

Оцінка рівня дотримання політичних прав і свобод в Криму заслуговує на окрему увагу. «Російська влада повністю знищила політичні права, унеможливила опозиційну політичну діяльність і переслідує будь-які прояви інакодумства на території окупованого Криму» [12]. За даними звіту, «рейтинг свободи в Криму встановлено на рівні "8" з 100 можливих. Серед всіх оцінених країн і територій окупований півострів опинився на 12 місці з кінця. Крім того Крим виявився в трійці країн i територій з найгіршим показником політичних прав» [9]. «Цьому, зокрема, сприяли організовані Росією утиски української та кримськотатарської громад для штучної зміни етнічного складу населення на користь росіян» [12]. Також звіт містить окремий розділ про непідконтрольність українському уряду Східному Донбасі, який отримав рейтинг 5/100 і зайняв місце в останній десятці країн і територій світу за рівнем прав і свобод.

На рейтинг свободи окупованого Донбасу негативно вплинули утиски української мови та ідентичності в цілому. У звіті відзначається «повна відсутність верховенства права та недотримання громадянських свобод, обмеження свободи ЗМI, арешти за повідомлення в соцмережах і тотальний контроль політичного життя з боку сепаратистів і Росії» [9]. Згідно зі звітом правозахисної організації Freedom House, «в Україні в 2020 році в порівнянні з 2019 роком на 2 пункти покращилася ситуація зі свободою: 60 - в 2019-м, 62 - d 2020 році. Політичні права експерти оцінили в 27 пунктів 3 40, а громадянські свободи - в 35 з 60. 3 такою оцінкою Україна відноситься до країн із статусом частково вільні» [12].

На думку О.Липчук «..сучасний стан захисту прав та свобод людини і громадянина в України свідчить про неналежні політико-правові умови його забезпечення, що, у свою чергу, ускладнює внутрішньополітичну ситуацію, спричиняє соціальне напруження та погіршує зовнішньополітичні позиції держави. В державній політиці правозахисна складова не $є$ виразною і наскрізною, а умови та гарантії забезпечення прав людини, залишаючись переважно на рівні декларацій, не $\epsilon$ системними та рівними для всіх, при тому що, в Україні наявна нормативна та організаційна основа» [5, с. 78]. Слід погодитися з тим, що «повага до прав людини, їхній захист та забезпечення є головним обов'язком держави» $[7$, с. 87$]$.

Деякі експерти вважають, що «каркас українського законодавства, що регламентує здійснення громадянами своїх політичних прав, вже створений....доопрацювання потребують виборчий закон (стосовно зменшення прохідного бар'єра, скасування заборони на участь у виборах політичних блоків, також громадян України, які відбули покарання), Закон «Про Всеукраїнський референдум» і решта документів, які регламентують форми політичної участі громадян» [8]. 
Висновки. Політичні права - це забезпечені юридично засоби можливої поведінки, які гарантують свободу дій громадян за участю у формуванні органів державної влади та місцевого самоврядування. Політичні права і свободи є одними з найбільш значущих в системі прав і свобод людини. Закріплення політичних прав та свобод в позитивному праві не скасовує їх природну природу, яка полягає в закладеному в людях прагненні до включення в суспільно-політичне життя.

Право громадян на участь в управлінні державою, на участь в діяльності політичної системи необхідно розглядати не як самодостатні, а як засоби здійснення загальнонародного права на владу, тобто вони, з одного боку, поряд з правом на владу деталізують право народу на самовизначення, а з іншого боку, $є$ засобом конкретизації самого права народу на владу.

Аналіз політичних прав та свобод неможливий поза дослідження політичного режиму, соціальноекономічних умов їх здійснення, напрямків розвитку держави, історичного шляху становлення цих прав. Відповідно підвищення ефективності політичних прав та свобод залежить від урахування всіх цих факторів.

Перспективним напрямом подальшого дослідження с дослідження у напрямку визначення нових критеріїв щодо рівня забезпечення політичних прав у різних країнах. Наприклад, це можуть бути такі питання: які групи людей в суспільстві особливо схильні до створення ситуації, коли їх права порушуються за кожним видом права; ступінь порушення в правах, коли права обмежуються державними особами в порівнянні з недержавними тощо.

\section{Бібліографічний список:}

1. Бук В. Зміст конституційних політичних прав і свобод. Право України. 2001. № 9. С. 21-23.

2. Гураль Л. Політичні права людини і громадянина в сучасній Україні. Вісник Прикарпатського університету. Політологія. 2016. Вип. 10. С. 125-130.

3. Ільницька У. В. Політичні права і свободи громадян: нормативно-правове забезпечення та механізми реалізації у демократичних державах. Наукові праці [Чорноморського державного університету імені Петра Могили]. Сер. : Політологія. 2012, Т. 197, Вип. 185. С. 37-41.

4. Кононенко Н. Політичні права і свободи в сучасній Україні: проблеми політичної практики.ІПіЕНД ім..І.Ф.Кураса НАН України. Наукові записки. 2018. №7. С.145-167.

5. Липчук О. І. Політичні права та свободи людини і громадянина: сучасний стан та проблеми реалізації в Україні/ Прикарпатський вісник НТШ. Думка. 2016. № 3. С. 72-78.

6. Людвік В. Д. Політичні права і свободи громадян України - основа принципу народного суверенітету. Вісник Харківського національного університету внутрішніх справ. 2005. Вип. 31. С. 375-380.

7. Плющ В.О. Державна політика щодо захисту прав і свобод людини в Україні. Державне управління. 2008. №11. C.86-89.

8. Резолюція ПАРЕ щодо функціонування демократичних інституцій в Україні 26.01.2012

9. Россия уничтожила политические права в Крыму - Freedom House . 07 марта 2020 года.

URL : https://www.pravda.com.ua/rus/news/2020/03/7/7242884/(дата звернення: 04.05.2020).

10. Скакун О.Ф. Теория государства и права. Х., 2000, 704.

11. Федоренко В. Політичні права та свободи людини і громадянина в Україні: поняття, види, характеристика. Історико-правовий часопис. 2016. №1 (7). С.80-86.

12. Щорічний звіт "Свобода у світі 2020" URL : https://freedomhouse.org/

\section{References:}

1. Buk V. Zmist konstituciinih politichnih prav i svobod. Pravo Ukraïni. 2001. № 9. S. 21-23.

2. Gural' L. Politichni prava lyudini i gromadyanina v suchasnii Ukraïni. Visnik Prikarpats'kogo universitetu. Politologiya. 2016. Vip. 10. S. 125-130.

3. Il'nic'ka U. V. Politichni prava i svobodi gromadyan: normativno-pravove zabezpechennya ta mehanizmi realizaciï u demokratichnih derjavah. Naukovi praci [CHornomors'kogo derjavnogo universitetu imeni Petra Mogili]. Ser. : Politologiya. 2012, T. 197, Vip. 185. S. 37-41.

4. Kononenko N. Politichni prava i svobodi v suchasnii Ukraïni: problemi politichnoï praktiki.IPiEND im..I.F.Kurasa NAN Ukraïni. Naukovi zapiski. 2018. №7. S.145-167.

5. Lipchuk O. I. Politichni prava ta svobodi lyudini i gromadyanina: suchasnii stan ta problemi realizaciï $\mathrm{v}$ Ukraïni/ Prikarpats'kii visnik NTSH. Dumka. 2016. № 3. S. 72-78.

6. Lyudvik V. D. Politichni prava i svobodi gromadyan Ukraïni - osnova principu narodnogo suverenitetu. Visnik Harkivs'kogo nacional'nogo universitetu vnutrishnih sprav. 2005. Vip. 31. S. 375-380.

7. Plyusch V.O. Derjavna politika schodo zahistu prav i svobod lyudini v Ukraïni. Derjavne upravlinnya. 2008. №11. S.86-89.

8. Rezolyuciya PARE schodo funkcionuvannya demokratichnih institucii v Ukraïni 26.01.2012

9. Rossiya unichtojila politicheskie prava v Krymu - Freedom House . 07 marta 2020 goda.

URL : https://www.pravda.com.ua/rus/news/ 2020/03/7/7242884/(data zvernennya: 04.05.2020).

10. Skakun O.F. Teoriya gosudarstva i prava. H., 2000, 704. 
11. Fedorenko V. Politichni prava ta svobodi lyudini i gromadyanina v Ukraïni: ponyattya, vidi, harakteristika. Istoriko-pravovii chasopis. 2016. №1 (7). S.80-86.

12. SCHorichnii zvit "Svoboda u sviti 2020" URL : https://freedomhouse.org/

\section{Pekhnyk A. V. Political rights and freedoms: actualization of the problem and assessment of the level of realization}

An important aspect of the consideration of political rights and freedoms is the regulation of political rights and freedoms at various levels. One of the main issues of any government is people's trust in its institutions. In a state-organized society, people's trust in the state directly depends on how the state guarantees and protects the rights and freedoms of people, the extent to which the state allows citizens to form and exercise their own will, to participate in the exercise of state functions. Here, we should pay attention to the political demands of citizens, which are subject to regulation in the implementation of political rights and freedoms. This is what this research work is aimed at.

Political rights and freedoms in our society have not yet become a full-fledged political and legal reality. On the one hand, the state does not always reliably ensure and guarantee these rights, freedoms, establishes unreasonable obstacles to the use of people's rights. On the other hand, citizens do not believe in the effectiveness of their influence on the government through political rights and freedoms. Therefore, the question arises - how to assess the level of observance in the state of political rights and freedoms of citizens. In most cases, when an attempt is made to assess the observance of political human rights, the analysis of documents that are available to the general public is usually used. However, this approach is not without its problems of incompleteness and uncertainty, as well as bias. As there is no objective data on this issue, it should be based on factual material, according to human rights experts who accumulate a global stock of knowledge make a real contribution to improving people's lives.

Key words: political rights, political freedoms, human rights, state, society. 